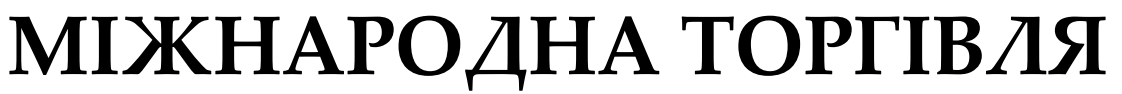

\author{
UDC 339.5:338.488 DOI: https://doi.org/10.31617/zt.knute.2020(109)06 \\ TKACHUK Tatiana Candidate of Economic Sciences, Associate Professor \\ at the Department of Hotel and Restaurant Business, \\ E-mail: t.tkachuk@knute.edu.ua \\ ORCID: 0000-0001-8657-2621 \\ Kyiv National University of Trade and Economics \\ Kyoto str., Kyiv, 02156, Ukraine
}

\section{LUXURY-SERVICE IN THE WORLD HOTEL SERVICE MARKET}

The development of luxury service in the international arena of hotel business is investigated and the key elements of its successful functioning are determined. The world luxury hotel brands are analyzed by categories according to the STR classification and the main criteria for choosing a hotel product (service) by a VIP client are identified in order to identify and analyze the trends of luxury service development in the global hotel services market.

Keywords: luxury-service, luxury hotel, VIP-client, luxury segment, hotel business stakeholders, hotel brand, luxury hotel services, world hotel services market, STR-classification.

Ткачук T. Lихигу-сервис на мировом рынке гостиничных услуг. Исследовано развитие lихигу-сервиса на международной арене гостиничного бизнеса и выделены ключевые элементы его успешного функиионирования. Проанализированы гостиничные бренды мира сегмента люкс по категориям в соответствии с STRклассификацией и определены основные критерии выбора гостиничного продукта (услуги) VIP-клиентом с иелью выявления и анализа тенденций развития lихигусервиса на мировом рынке гостиничных услуг.

Ключевые слова: luxигу-сервис, элитный отель, VIP-клиент, люкссегмент, стейкхолдеры гостиничного бизнеса, гостиничный бренд, роскошные гостиничные услуги, мировой рынок гостиничных услуг, STR-классификация.

Background. The main tendencies of functioning and development of modern society are the maximum automation of the activity, personalized approach to the client, the uniqueness of the offered goods (services) and its authenticity. These trends are observed in many types of economic activity. The sphere of hotel services is no exception.

(C) Tkachuk T., 2020 
The positive dynamics of tourism development is one of the key factors that leads to the construction of new hotels and contributes to the quality improvement of its services for clients. According to the results of the analysis of the functioning of the international tourist market, it is possible to say that the segment of consumers preferring elite holidays has increased. First of all, this is accompanied by the rapid development of the range of needs of the modern client and the increase of his requirements for the uniqueness of the offered product (service) regardless of the purpose of the trip. And as a result, the number of luxury hotels is actively increasing.

However, there is a lack of unity of approaches of entrepreneurs to understanding the essence of the concept of elite, the discrepancy of the offered services to the demands of the modern elite client, the imperfection of price policy regulation, as well as instability of the index of investment attractiveness of Ukraine in the world ranking. First of all, it leads to the low dynamics of development of international hotel chains in the Ukrainian market, which determines the relevance of research of the trends of hotel market development for the segment of elite clients in the international arena.

Analysis of recent research and publications. With the growing popularity of personalization and the uniqueness of the offered hotel product and, consequently, the increase in the number of hotels that position themselves as providers of elite services, the research of the development features of this market segment becomes relevant.

The works of domestic and foreign scientists are dedicated to the hotel management issues and its classification for luxury segment customers, the formation of an elite brand of hotel chain, among them: R. Canani, J. Matsalovo, E. Rigo-Lacress, M. Chevalier, O. Shykina [1-4]. Some aspects regarding the identification of the concepts of luxury and elite, modeling the consumer behavior and service quality for the clients of luxury-segment in the sphere of hotel business were considered by scientists A. Abuhalife, S. Berh, H. Dovhal, I. Korol, K. Lou, M. Marek, X. Minh, N. Pavlishyn, I. Skorobogatykh, A. Poad Mat Som, B. Chen [5-11]. The review of domestic and foreign scientific works shows the increasing popularity of the elite hotels development in the services market. However, the issue of the formation of key aspects and tendencies of luxury-service development in the hotel business is insufficiently studied and remains a relevant area of scientific research.

The purpose of the article is to identify and analyze the main trends and key elements of luxury service development in the global hotel services market.

Materials and methods. The methodological basis of the article is the statistical and graphical methods by which the dynamics of development of luxury-service in the global hotel services market is analyzed. The information base for the scientific research was the works of domestic and foreign scientists and online sources of relevant thematic direction.

Results. The modern conditions of operation of the hotel business enterprises, including global competition in the market, the speed of 
changing customer needs and their demand for services, the dynamic popularization of personification of approaches to the creation of unique hotel product, as well as the rapid development of the tourism industry as a whole, encourage them to make more adaptable decisions about further successful activities.

The direction of creating a luxury product (service) for the relevant segment of customers is of particular relevance and development in the global hotel services market. This term is a Ukrainian interpretation of the English word «luxury». The term «luxury» is synonymous with the identifycation of goods (services) in this class. According to the results of a marketing research conducted in eight countries of Western Europe, the main lexical components of the concept of «luxury goods» were identified: expensiveness, quality, exclusivity and desirability [11].

The specifics of creating a luxury product or service in a hotel business are, first and foremost, customer orientation, which, unlike a significant number of consumers, is able to make a purchase. On the one hand, the sale of such goods (services) is no different than others, since the level of these sales is influenced by the same factors and regularities. On the other hand, luxury is an exclusive commodity. And the phenomenon of consumption of exclusive goods (services) remains poorly studied. This is due to the fact that the elite market violates all the rules; it exists outside the traditional models. This is supported by the fact that the luxury market is almost unresponsive to the financial downturns in the economy. Such a phenomenon testifies to the specificity of the creation and provision of luxury services [10].

According to research from consulting company Allied Analytics LLP; the size of the global luxury travel market in 2018 was 891 billion USD. It is projected to increase by $7.9 \%$ in $2019-2026$ [12]. The luxury travel market is expected to be the fastest growing segment of the tourism industry worldwide. The main drivers of the luxury travel trend are people's inclination to unique and exotic holidays while vacationing, increasing middle-class and upper-class income and the associated costs, as well as increasing family travel needs and interest.

Private jets, exotic resorts, the authenticity of provided services, private yachtsand private island rentals are unique services offered by the hotel business stakeholders to luxury segment clients. Today's tourists focus on experiments with directions to get a unique and unforgettable experience during cultural visits, cruise holidays, extreme traveland food consumption culture from around the world etc.

Demand for the luxury hotel market is increasing due to the increase in the number of business meetings and the pace of development of the tourism industry as a whole. In addition, the globalization of the market, industrialization and urbanization directly regulate the luxury hotel market. For the most part, such hotels do not have clear standards, and the main criteria for their identification are the high quality and, accordingly, the cost of accommodation and food, as well as a wide range of unique services. 
The luxury hotel market is evaluated at 82.77 billion USD, and it is expected to cost 114.35 billion USD by 2025 , considering the growing CAGR level of $4.1 \%$ from 2018 to 2025 . Such dynamics of increase of indicators are conditioned, first of all, by the annual increase in the number of Chinese tourists to the United States, which are a source with high costs. From 2016 to 2018, average spending per tourist increased by $3.2 \%$ - from 2534 to 2,700 USD [13].

Among the countries in the world, the United States accounts for the largest share of revenue in the luxury hotel services market $(75.5 \%)$. In addition, there is a growing demand for international luxury travel in developing countries (China, India). This trend is explained by the increase in per capita income of middle-class tourists in developing countries (Figure 1).
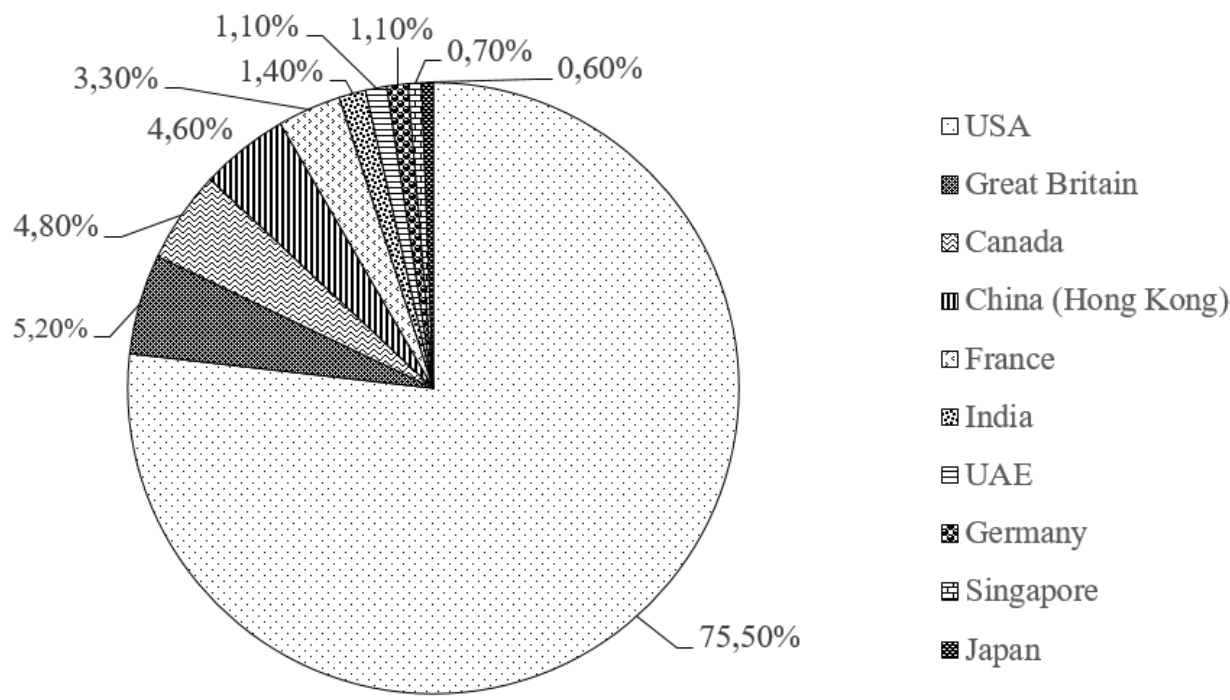

Figure 1. The share of revenues from luxury-services of the leading countries in the global hotel services market, \%

Source: Compiled by the author for [14].

It is advisable to analyze trends in the development of luxury services in the US hotel services market as a major leader in the research area. According to the results of the analytical report of the consulting company Global Data, the number of luxury hotels in 2019 was 1067 units, which are 20 units more than in the previous year. This figure is expected to reach 1123 units by 2022 as to the overall annual growth rate of $1.7 \%$ (Figure 2).

According to the research of the dynamics of the level of entrepreneurs' interest in the development of the hotel business, in the luxury segment in the international market of services the growth of such indicator is determined by $1.5 \%$ in 2019 compared to the previous year. The main geographical locations of potential development of luxury hotels are the United States (66.3\%), the United Kingdom (13.3\%), China (5.2\%), Germany (4\%) and India (3.8\%) [14]. 


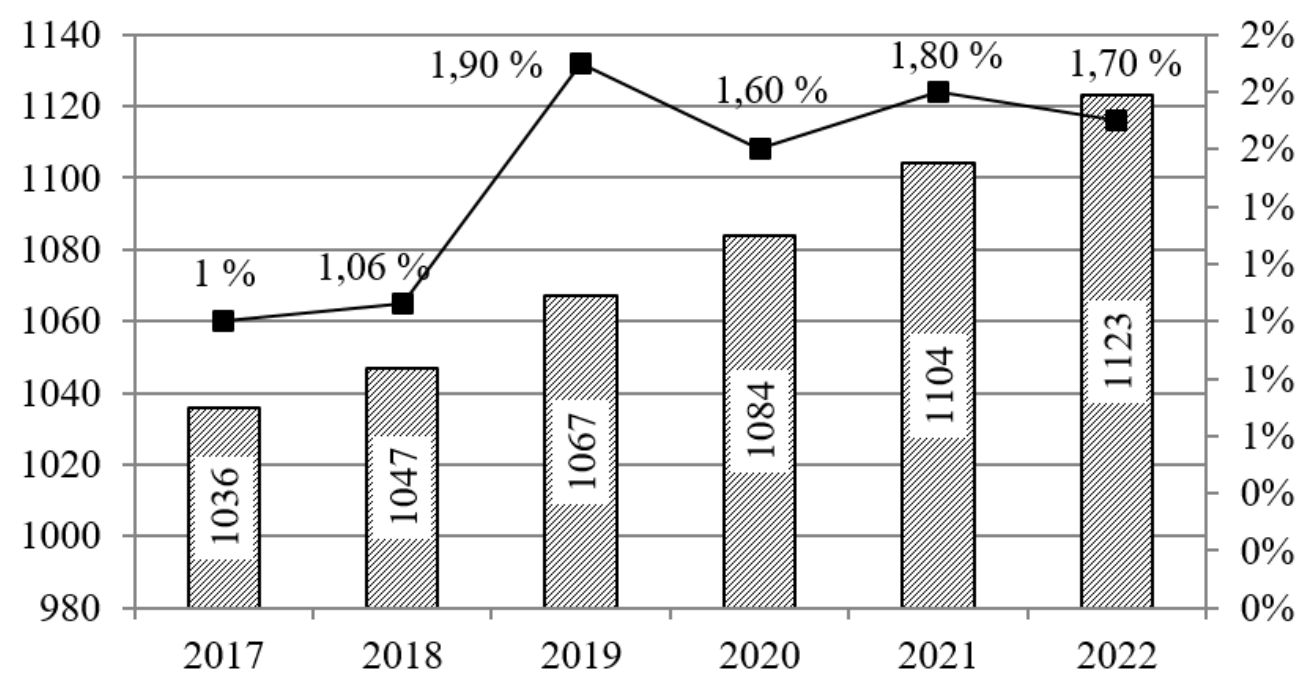

Number of luxury hotels $\quad \rightarrow$ units Growth rate, \%

Figure 2. The dynamics of the number of luxury US hotels in 2017-2019 and its forecast development in 2020-2022

Source: compiled by the author for [13].

One of the key elements of the creation and development of luxury services in the global hotel services market is the formation of luxury brands. The research highlights its major categories, which are adapted to the international Smith Travel Research (STR) classification. These categories include hotel brands which offer high-quality accommodation and lodging to clients with an appropriate wide range of services. The main difference between these categories is the value of the average rate of sales (ADR).

Therefore, the categories of luxury hotel brands include:

- luxury major - the average hotel room sales rate $(A D R)$ in this category is typically greater than 210 USD. The main representatives are the brands of well-known hotel chains worldwide, including Fairmont, Grand Hyatt, Inter Continental, JW Marriott, Ritz-Carlton, Sofitel, Waldorf Astoria;

- upper upscale - the average hotel room sales rate $(A D R)$ in this category is 145 to 210 USD. The key brand representatives: Hilton, Hyatt, Kimpton, Pan Pacific, Radisson Blu Hotel, Sheraton, Westin, Wyndham;

- luxury exclusive (small / medium sized) with an ADR value of 110 to 145 USD. These brands include Banyan Tree, Four Seasons, Kempinski, Mandarin Oriental, Oberoi, Shangri-La, Six Sensesand Trump Hotel [14].

Luxury exclusive brands account for the largest share of the hotel services market $-40.5 \%$. The share of upper upscale and luxury major hotel brands is $38 \%$ and $21.4 \%$ respectively. At the same time, among the aforementioned brands, the fastest growing category is luxury major $(12.1 \%)$, while in the luxury exclusive brand it is $5.6 \%$.

By predefined criteria, the table presents the main characteristics of the above categories of luxury hotel brands. 
Characteristics of luxury brands in the hotel business by $S T R$ classification

\begin{tabular}{|c|c|c|c|}
\hline Category & Specifics & $\begin{array}{c}\text { TOP } \\
\text { destinations }\end{array}$ & $\begin{array}{l}\text { Hotel brands - } \\
\text { representatives } \\
\text { of the category }\end{array}$ \\
\hline $\begin{array}{l}\text { Luxury- } \\
\text { major }\end{array}$ & $\begin{array}{l}4.6 \% \text { of global demand in the } \\
\text { hotel services market; } \\
\text { a } 1.7 \% \text { increase in market share } \\
\text { compared to previous years; } \\
\text { India is the fastest growing } \\
\text { hotel brand market in this } \\
\text { category }(59 \%)\end{array}$ & $\begin{array}{l}\text { USA (Atlanta, } \\
\text { New Orleans, } \\
\text { Florida, Hawaii } \\
\text { (Maui)); } \\
\text { Italy (Naples) }\end{array}$ & $\begin{array}{l}\text { Andaz, Bulgari } \\
\text { Hotels, Conrad, } \\
\text { Fairmont, Gran } \\
\text { Melia, Grand Hyatt, } \\
\text { Hotel Missoni, } \\
\text { InterContinental, JW } \\
\text { Marriott, ME hotel, } \\
\text { Park Hyatt, Raffles, } \\
\text { Ritz-Carlton, Royal } \\
\text { Tulip, Sofitel, St. } \\
\text { Regis, WHotel } \\
\text { Waldorf Astoria }\end{array}$ \\
\hline $\begin{array}{l}\text { Upperups } \\
\text { cale }\end{array}$ & $\begin{array}{l}22.8 \% \text { of global demand in the } \\
\text { hotel services market; } \\
\text { decrease in the market share by } \\
1.6 \% \text { compared to previous } \\
\text { years; } \\
\text { India is the fastest growing } \\
\text { hotel brand market in this } \\
\text { category }(16.7 \%)\end{array}$ & $\begin{array}{l}\text { USA (New York, } \\
\text { Las Vegas, } \\
\text { Hawaii, } \\
\text { Chicago); } \\
\text { United Kingdom } \\
\text { (London) }\end{array}$ & $\begin{array}{l}\text { Camino Real Hotel, } \\
\text { Dusit Thani, } \\
\text { Embassy Suites, } \\
\text { Gaylord Hotel, } \\
\text { Hilton, Hotel du Vin, } \\
\text { Hyatt, Joie De Vivre, } \\
\text { Kimpton, Le } \\
\text { Méridien, Mgallery, } \\
\text { Millennium Hotel, } \\
\text { Nikko, Okura Hotel, } \\
\text { Omni Hotel, Pan } \\
\text { Pacific, Pullman } \\
\text { Hotel, Radisson Blu } \\
\text { Hotel, Renaissance, } \\
\text { Sheraton, Steigen- } \\
\text { berger, Swissotel, } \\
\text { Vivantaby Taj, } \\
\text { Westin, Wyndham }\end{array}$ \\
\hline $\begin{array}{l}\text { Luxuryex } \\
\text { clusive } \\
\text { (small/ } \\
\text { medium- } \\
\text { sized) }\end{array}$ & $\begin{array}{l}4.8 \% \text { of global demand in the } \\
\text { hotel services market; } \\
\text { a } 2.7 \% \text { increase in the market } \\
\text { share compared to previous years; } \\
\text { the UK is the fastest growing hotel } \\
\text { brand of this category }(12.4 \%)\end{array}$ & $\begin{array}{l}\text { USA (New York, } \\
\text { Las Vegas, } \\
\text { Hawaii (Maui), } \\
\text { Chicago); } \\
\text { France (Bora } \\
\text { Bora Island) }\end{array}$ & $\begin{array}{l}\text { Affinia, African } \\
\text { Pride Hotel, Anantara, } \\
\text { Angsana, Banyan } \\
\text { Tree, Four Seasons, } \\
\text { Guoman, Hospes, } \\
\text { Impiana Hotel, } \\
\text { Jumeirah, Kempinski, } \\
\text { Langham, Loews, } \\
\text { Lotus Resort, } \\
\text { Mandarin Oriental, } \\
\text { Oberoi, One\&Only, } \\
\text { Orient-Express } \\
\text { Hotel, Peninsula, } \\
\text { Regalia Hotel, Regent, } \\
\text { Rock Resorts, Rose- } \\
\text { wood, Shangri-La, } \\
\text { Six Senses, Taj } \\
\text { Hotel, The Leela, } \\
\text { Trump Hotel }\end{array}$ \\
\hline
\end{tabular}

Source: compiled by the author for [14]. 
According to the research conducted by Digital Luxury Group, the most popular luxury hotel segment groups in the global services market were identified (Figure 3).

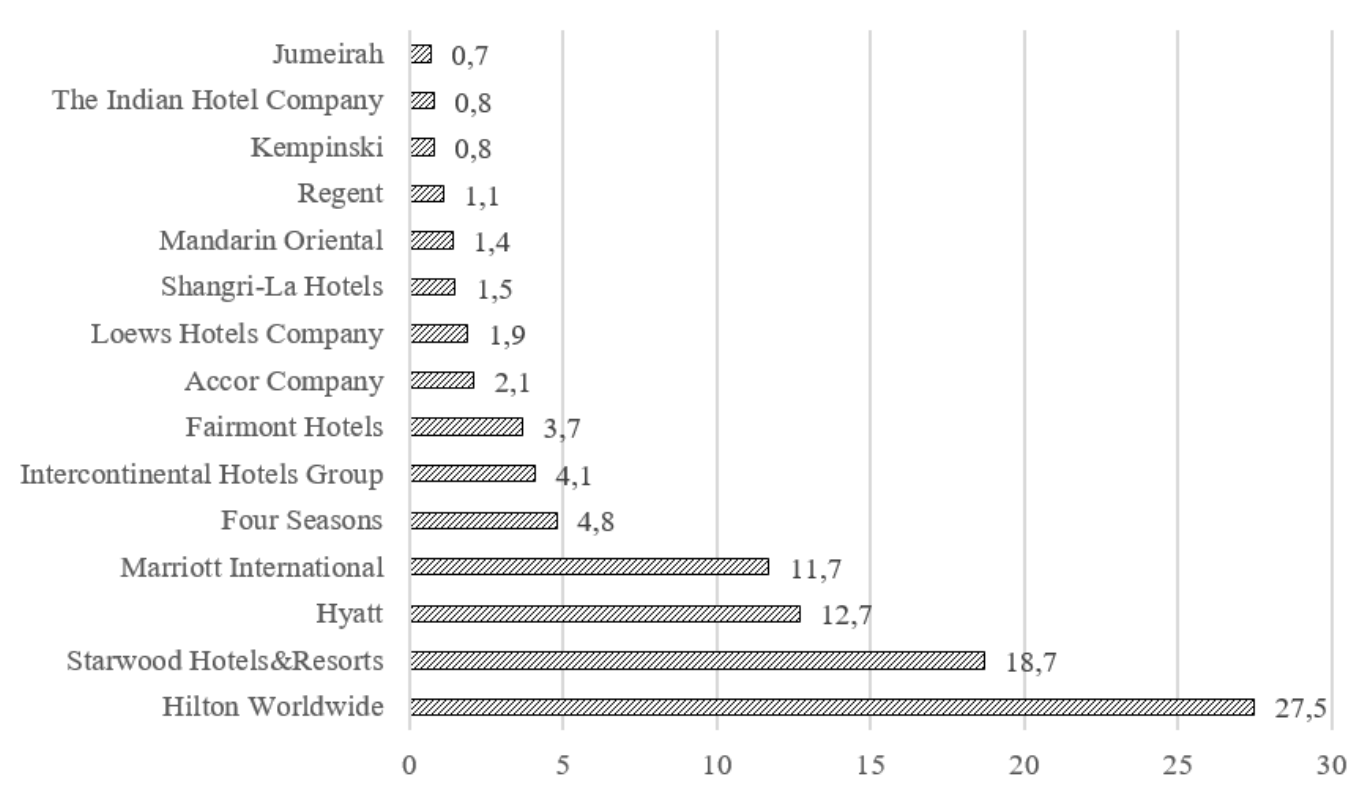

Figure 3. Shares of luxury-segment hotel groups in the global services market, $\%$

Source: compiled by the author for [14].

The modern client of the luxury hotel business enterprises is more demanding in the choice of the product (service). The main criteria for his choice have become emotional (gaining special experience, personalization and non-tradition of approaches to service, wide range and the exotic nature of the offered services, the availability of highly qualified staff), information and technological component (innovative technologies and systems of service, including the use of modern Internet of Things platforms (IoT) and custom mobile applications for hotel room management, etc.). Consequently, the customers of the luxury segment prefer the comfort and quality of service. Instead, the cost of staying at a hotel and the cost of offered services are a secondary issue for them. Therefore, in order to achieve sustainable long-term growth, hoteliers need to have a deep understanding of the type of clients they want to attract, and to offer an experience adapted to a specific group. The hotel businesses are more suited to the preferences of real and potential guests in their segment, so they can more accurately navigate and build meaningful, lasting relationships with them.

According to Global Data, the total number of guests staying in luxury hotels has increased from 186.3 million (2009) to 306.3 million (2017) and it is expected to reach 394.6 million by 2021 [15]. The luxury 
hotel segment's market share in 2017 was approximately $80 \%$ against other segments. Luxury customers spent an average of 910 USD at the most frequently visited hotel for the last year (against economy class consumers who spent about 176 USD in the same period) [16].

Conclusion. The study of the architectonics of the hotel business luxury segment in the world market determined the main trends of its development and functioning.

Unique and personalized service with the use of innovative systems and technologies: the use of smart-room technologies to individualize the stay of the client; deviation from standards when a customer is staying at a hotel and favoring modern Internet of Things platforms; working closely with representatives of IT companies in the field of hotel business.

Leaders of active use of modern systems and technologies in its activities for personalized customer service of the luxury segment are Shangri - La hotel brands (cooperation with Tencent company); Marriott (Samsung, Legrand, IoT Guestroom Lab), Accor Hotels (Google).

The authenticity of services and gaining local experience. Modern luxury customers have a strong demand for local color, often looking for opportunities, amenities and services to get to know their visitor with culture of the place of visit as closely as possible. Based on such customer requirements, the hotels, above all, create the relevant product (service), taking into account the specific features of the location (culture, local cuisine, etc.).

Increasing popularity of wellness trips and wellness tourism. According to the research in the tourism industry in recent years, it can be argued about the promotion of healthy lifestyles, in particular among customers of the luxury segment, which contributed to the active development of the hotel business in this direction. International hotel chains are integrating wellness content into their service model, starting from the design of the hotel's exterior to the day-to-day operations on quality guest service. Thus, the well-known hotel chain Ritz-Carlton has 13 new rooms of wellness direction, each of which focuses on one of the three elements of wellness: comfort, rest, fitness. Aromatherapy bath salts are offered to clients; showers supplying water filled with vitamin C; yoga mats; air purifiers and etc.

Promoting emotionality of impressions. In modern conditions of accelerated development of information systems and technologies in the hotel services market there is an active corresponding staff exchange. Due to this tendency, international hotel brand policies are focused on the close interaction of staff and customer to improve the quality of service and to receive positive impressions from both the services offered separately and the hotel brand as a whole.

The active expansion of holiday "weekend", which led to a reduction in the length of stay of the client in the hotel. According to statistics, in 2019, $53 \%$ of travelers (including the luxury category) stayed in hotels 
only on weekends or holidays, and this is projected to increase. The main trend and cause for the growing popularity of this trend is «foodies", i.e. travel in order to get a culinary experience. Taking it into account, hotels are focused on organizing specialized cooking courses based on local cuisine, cooking and menu entry of organic ingredients etc.

The development of concierge services to improve customer comfort and interaction with him.

Thus, the promotion and development of the luxury segment in the global hotel services market is growing and, consequently, causes high competition not only among the hotel business enterprises, but also among other active stakeholders in the market. However, some of the issues outlined, such as the formation of luxury services depending on the location of the hotel, the business models of the categories of luxury hotels, the creation of service culture and standards of VIP-customer service, are poorly researched and require thorough study to further implementation in the domestic hotel services market.

\section{СПИСОК ВИКОРИСТАНИХ ДЖЕРЕ}

1. Kanani R. B. A wealth of in sight: The World's Best Luxury Hotelierson Leadership, Management, and the Future of 5-Star Hospitality, 2017. 333 p.

2. Mazalovo G., Chevalier M. Luxury Brand Management: A World of Privilege, 2012.320 p.

3. Rigaud-Lacresse E. New Luxury Management, 2017. $311 \mathrm{p}$.

4. Шикіна О. В. Теоретичні основи діяльності концептуальних готелів та їхня класифікація. Східна Свропа: економіка, бізнес та управління. 2017. Вип. 6 (11). С. 212-219.

5. Abukhalifeh A. N., Som A. P. Customer Perceptions of Service Quality in Luxury Hotels in Petra and Aqaba, Jordan: An Exploratory Study. International Journal of Tourism \& Hospitality Review (IJTHR). 2014. Vol. 1. P. 37-44.

6. Berchoux C., Carol Lu, etc. Service Quality and Customer Satisfaction: Qualitative Research Implications for Luxury Hotels. International Journal of Culture Tourism and Hospitality Research. 2015. № 9(2). P. 168-175.

7. Довгаль Г. В. Сучасні тенденції розвитку світового готельного бізнесу. Вісник ХНУ ім. В. Н Каразіна. Міжнародні відносини. Економіка. Країнознавство. Туризм. 2019. Вип. 9. С. 190-196.

8. Король I. В. Маркетинг розкоші: принципи побудови успішного люксового бренду. Миколаївський національний університет імені В. О. Сухомлинського. Економіка та управління підприємствами. 2016. Вип. 11. С. 396-399.

9. Min H. Measuring the service quality of luxury hotel chainsin the USA International Journal of Services and Operations Management. 2018. Vol. 30, No. 4. P. 465-479.

10. Павлішина Н. М. Маркетинг розкоші, моделювання поведінки споживача розкоші. Науковий вісник Полтавського університету економіки $i$ торгівлі. 2014. № 2 (64). С. 94-99. 
11. Скоробогатых И. И. Семантический аналіз понятия роскоши (результаты международного маркетингового исследования). URL : http://www.marketologi.com/publikatsii/stati/semanticheskijj-analizponjatija-roskoshi.

12. Сайт консультаційної компанії Allied Analytics LLP. URL : https://www.alliedmarketresearch.com/luxury-travel-market.

13. Сайт аналітичної компанії Global Data, Travel \& Tourism Intelligence Center. URL : https://www.globaldata.com.

14. Сайт світової дослідницької компанії Digital Luxury Group. URL : http://www.digital-luxury.com/reports/World_Luxury_Index_Hotels_by_Digital_ Luxury_Group.pdf.

15. Сайт міжнародного видавництва TRAVEL TRADE. URL : https://traveltradedaily.com/europe-news/item/4162-luxury-travel-marketgrowing-globaldata.

16. Сайт бізнес-журналу From Economy to Luxury. What Matters Mostto Hotel Guests. URL : https://news.gallup.com/businessjournal/175568/economyluxury-matters-hotel-guests.aspx.

The article submitted to editor's office on 20.01.2020.

Ткачук Т. Lихигу-сервіс на світовому ринку готельних послуг.

Постановка проблеми. Позитивна динаміка розвитку туризму $\epsilon$ одним із ключових факторів зростання кількості готелів на ринку. Аналіз функиіонування міжнародного туристичного ринку показує, щзо сегмент споживачів, які віддають перевагу елітному відпочинку, збільшується, щь своєю чергою супроводжується швидким розвитком потреб сучасного клієнта та його вимог щьодо унікальності пропонованого товару (послуг) незалежно від мети поїзки. Це сприяє активному розвитку та зростанню кількості розкішних готелів і визначає актуальність дослідження тенденцій на готельному ринку для сегмента елітних клієнтів на міжнародній арені.

Метою дослідження є визначення та аналіз основних тенденцій i ключових елементів розвитку lихигу-сервісу на світовому ринку готельних послуг.

Матеріали та методи. Методологічною основою наукового дослідження $\epsilon$ статистичний та графічний методи, завдяки яким проаналізовано динаміку розвитку lихигу-сервісу на світовому ринку готельних послуг. Інформаційною базою для дослідження стали прачі вітчизняних та іноземних науковців ци інтернет-джерела відповідного тематичного спрямування.

Результати дослідження. Простежено розвиток lихигу-сервісу на міжнародній арені готельного бізнесу та виокремлено ключові елементи його успішного функиіонування. Проаналізовано готельні бренди світу сегмента люкс за категоріями відповідно до STR-класифікачіï та розглянуто основні критерії вибору готельного продукту (послуги) VIPклієнтом з метою виявлення та аналізу тенденцій розвитку lихигу-сервісу на світовому ринку готельних послуг.

Висновки. Динаміка розвитку туризму, яка позитивно зростає щзороку, $\epsilon$ одним із ключових факторів, щчо безпосередньо визначає збільшення кількості готелів та якості наданих послуг для різних сегментів 
клієнтів. Результати аналізу функціонування міжнародного туристичного ринку показують, щуо кількість споживачів, що віддають перевагу елітному відпочинку, зростає, i ие, передусім, супроводжується швидким розвитком потреб сучасного клієнта та його вимог щзодо унікальності пропонованого товару (послуг) незалежно від мети поїзки. Це сприяє активному розвитку та зростанню розкішних готелів. Тож, дослідження проблем розвитку та тенденцій готельного ринку для сегмента елітних клієнтів на міжнародній арені є актуальним для подальщої імплементації на українському ринку готельних послуг.

Ключові слова: luxury-сервіс, елітний готель, VIP-клієнт, люкссегмент, стейкхолдери готельного бізнесу, готельний бренд, розкішні готельні послуги, світовий ринок готельних послуг, $S T R$-класифікація.

\section{REFERENCES}

1. Kanani, R. B. (2017). A wealth of insight: The World's Best Luxury Hotelierson Leadership, Management, and the Future of 5-Star Hospitality [in English].

2. Mazalovo, G., \& Chevalier, M. (2012). Luxury Brand Management: A World of Privilege [in English].

3. Rigaud-Lacresse, E. (2017). New Luxury Management [in English].

4. Шикіна, О. В. (2017). Teoretychni osnovy dijal'nosti konceptual'nyh goteliv ta i'hnja klasyfikacija [The oretical bases of activity of conceptual hotels and its classification]. Shidna Jevropa: ekonomika, biznes ta upravlinnja Eastern Europe: economics, business and management. (Is. 6 (11), (pp. 212219) [in Ukrainian].

5. Abukhalifeh, A. N., \& Som, A. P. (2014). Customer Perceptions of Service Quality in Luxury Hotels in Petra and Aqaba, Jordan: An Exploratory Study. International Journal of Tourism \& Hospitality Review (IJTHR). (Vol. 1), (pp. 37-44) [in English].

6. Berchoux, C., Carol, Lu, et al. (2015). Service Quality and Customer Satisfaction: Qualitative Research Implications for Luxury Hotels. International Journal of Culture Tourism and Hospitality Research, 9 (2), (168-175) [in English].

7. Dovgal', G. V. (2019). Suchasni tendencii' rozvytku svitovogo gotel'nogo biznesu [Modern tendencies of development of the world hotel business]. Visnyk HNU im. $V . N$ Karazina. Mizhnarodni vidnosyny. Ekonomika. Krai'noznavstvo. Turyzm - The journal of V. N. Karazin KhNU. International relations. Economics. Country Studies. Tourism, (Is. 9), (pp. 190-196) [in Ukrainian].

8. Korol', I. V. (2016). Marketyng rozkoshi: pryncypy pobudovy uspish-nogo ljuksovogo brendu. Mykolai'vs'kyj nacional'nyj universytet imeni V. O. Suhomlyns'kogo [Luxury marketing: the principles of building a success ful luxurybrand. Mykolaiv V. O. Sukhomlynskyi National University]. Ekonomika ta upravlinnja pidpryjemstvamy - Business economics and management, (Is. 11), (pp. 396-399) [in Ukrainian]. 
9. Min, H. (2018). Measuring the service quality of luxury hotel chainsin the USA. International Journal of Services and Operations Management, (Vol. 30), 4, 465-479 [in English].

10. Pavlishyna, N. M. (2014). Marketyng rozkoshi, modeljuvannja povedinky spozhyvacha rozkoshi [Luxury marketing, luxury consumer be havior modeling]. Naukovyj visnyk Poltavs'kogo universytetu ekonomiky i torgivli Scientific bulletin of Poltava University of Economics and Trade, 2 (64), 94-99 [in Ukrainian].

11. Skorobogatyh, I. I. (n.d.). Semanticheskij analiz ponjatija roskoshi (rezul'taty mezhdunarodnogo marketingovogo issledovanija) [The semantic analysis of the conceptof luxury (results of international marketing research)]. marketologi.com Retrieved from http://www.marketologi.com/publikatsii/stati/semanticheskijjanaliz-ponjatija- roskoshi [in Russian].

12. Sajt konsul'tacijnoi' kompanii' Allied Analytics LLP [Website of consulting company Allied Analytics LLP]. Retrieved from https://www.alliedmarketresearch.com/luxury-travel-market [in English].

13. Sajt analitychnoi' kompanii' Global Data, Travel \& Tourism Intelligence Center [Website of the analytical company Global Data, Travel \& Tourism Intelligence Center]. Retrieved from https:/www.globaldata.com [in English].

14. Sajt svitovoi' doslidnyc'koi' kompanii' Digital Luxury Group [The site of a world research company Digital Luxury Group]. Retrieved from http://www.digital-luxury.com/reports/World_Luxury_Index_Hotels_by_ Digital_Luxury_Group.pdf [in English].

15. Sajt mizhnarodnogo vydavnyctva TRAVEL TRADE [Website of international publishing house TRAVEL TRADE]. Retrieved from https://traveltradedaily.com/europe-news/item/4162-luxury-travel-marketgrowing-globaldata [in English].

16. Sajt biznes-zhurnalu From Economy to Luxury. What Matters Mostto Hotel Guests [Business magazine website From Economy to Luxury. What Matters Most to Hotel Guests]. Retrieved from https://news.gallup.com/ business journal/175568/economy-luxury-matters-hotel-guests.aspx [in English]. 